\title{
Membrane Properties of Ameboid Microglial Cells in the Corpus Callosum Slice from Early Postnatal Mice
}

\author{
J. Brockhaus, ${ }^{1}$ S. Ilschner, ${ }^{1}$ R. B. Banati, ${ }^{2}$ and H. Kettenmannn ${ }^{1,3}$ \\ 'Department of Neurobiology, University of Heidelberg, 69120 Heidelberg, Germany, ${ }^{2}$ Max-Planck-Institut für Psychiatrie, \\ 82152 Planegg-Martinsried, Germany, and ${ }^{3}$ Max-Delbrück-Center, 13122 Berlin-Buch, Germany
}

\begin{abstract}
Microglial cells in culture are distinct from neurons, macroglial cells, and macrophages of tissues other than brain with respect to their membrane current pattern. To assess these cells in the intact tissue, we have applied the patchclamp technique to study membrane currents in microglial cells from acute, whole brain slices of 6-9-d-old mice in an area of microglial cell invasion, the cingulum. As strategies to identify microglial cells prior to or after recording, we used binding and incorporation of Dil-acetylated low-density lipoproteins, binding of fluorescein isothiocyanate-coupled IgG via microglial Fc-receptors, and ultrastructural characterization. As observed previously for cultured microglial cells, depolarizing voltage steps activate only minute if any membrane currents, while hyperpolarizing voltage steps induced large inward currents. These currents exhibited properties of the inwardly rectifying $\mathrm{K}^{+}$channel in that the reversal potential depended on the transmembrane $\mathrm{K}^{+}$gradient, inactivation time constants decreased with hyperpolarization, and the current was blocked by tetraethylammonium $(50 \mathrm{~mm})$. This study represents the first attempt to assess microglial celis in situ using electrophysiological methods. It opens the possibility to address questions related to the function of microglial cells in the intact CNS.

[Key words: microglia, brain macrophages, electrophysiology, patch-clamp technique, $\mathrm{K}^{+}$channels, brain slices, cingulum, development]
\end{abstract}

In contrast to neurons, astrocytes, or oligodendrocytes, which are all ectodermal, microglial cells are of mesodermal origin, developing from bone marrow-derived monocytes. They invade the brain during embryonic development (Perry et al., 1985; Dickson, 1991) at specific locations in the CNS, called "fountains of microglia" by del Rio-Hortega (1932) or "hot spots" by Perry et al. (1985), where migratory forms of microglia are found in large numbers. Hickey et al. (1992) demonstrated the origin of the perivascular subpopulation of microglia in experiments with bone marrow chimera in adult animals. During embryonic development until the early postnatal period they migrate into essentially all brain areas and distribute throughout

\footnotetext{
Received Sept. 18, 1992; revised Apr. 20, 1993; accepted Apr. 29, 1993.

This research was supported by the Bundesministerium für Forschung und Technologie and the Deutsche Forschungsgemeinschaft. We thank T. Berger, D. Büringer, and I. Milojevic for excellent technical assistance and K. Brückner for help with photography.

Correspondence should be addressed to Dr. H. Kettenmann, MDC, RobertRössle Strasse 10, 13122 Berlin-Buch, Germany.

Copyright (C) 1993 Society for Neuroscience $0270-6474 / 93 / 134412-10 \$ 05.00 / 0$
}

all parts of the CNS. From the active and migratory form they then convert into their resting state characterized by the formation of extensive processes (del Rio-Hortega, 1921; Kershmann, 1939; Leong and Ling, 1992). In pathological conditions they can become activated (Graeber et al., 1988) and, for example, phagocytic (Streit et al., 1988).

While the morphological appearance of microglia in brain tissue has been described in early anatomical studies (del RioHortega, 1932; Kershman, 1939), studies of the functional properties of microglia were mainly conducted in tissue culture. $\mathrm{Pu}$ rified microglial cultures can be obtained from primary brain cultures (Giulian and Baker, 1986; Frei et al., 1987). These activated microglia have surface markers similar to that of macrophages from other tissues, for example, receptors for acetylated low-density lipoproteins (ac-LDL; Giulian and Baker, 1986; Giulian et al., 1989). Patch-clamp studies, however, revealed a striking difference between microglial cells and peripheral macrophages: while macrophages from the peritoneal cavity are characterized by in- and outwardly rectifying $\mathrm{K}^{+}$currents, in cultured microglial cells only an inwardly rectifying $\mathrm{K}^{+}$current was detected (Kettenmann et al., 1990). In culture, this channel pattern can serve as a cellular marker, since it distinguishes microglial cells from macrophages on one hand, and also from astrocytes, oligodendrocytes, and neurons on the other. In fact, the only other cell type in the body with a similar channel pattern found so far is a subpopulation of bone marrow macrophagelike precursor cells (Banati et al., 1991).

To confirm the relevance of the electrophysiological data obtained from cultured microglia, it is important to establish what types of ion channels are expressed in microglia in situ. To address these questions, we have recorded from microglial cells in a state functionally comparable to the situation in culture, namely, during the migratory phase in early postnatal development. We have selected cells in the cingulum, a characteristic site of microglial invasion (Leong and Ling, 1992). Referring to Giulian and Baker (1986) we use the descriptive name "ameboid microglia." In this study, we demonstrate that these cells express an ion channel pattern similar to that of cultured microglial cells. This verifies that the electrophysiological properties of cultured microglia reflect characteristics of a defined population of microglial cells in vivo.

\section{Materials and Methods}

Preparation of brain slices and recording setup. The preparation was performed as previously described for recording from oligodendrocytes of the corpus callosum (Berger et al., 1991). The forebrain hemispheres of young mice (aged postnatal day 6-9) were cut into $150 \mu \mathrm{m}$ thin coronal slices using a vibratome (FTB, Plano, Marburg, Germany). Slices were stored in ice-cold $\mathrm{O}_{2}$-gassed solution prior to use for electrophysiology. 
For the patch-clamp expcriments a slice was placed into a recording chamber mounted on the stage of a Zeiss upright microscope; the slice was held in place by a grid of nylon threads framed by an U-shaped platinum wire. The chamber was continuously perfused with standard salt solution as described below. Substances were introduced by changing the perfusate. Cells in the corpus callosum near to or on the surface of the slice were viewed with $40 \times$ water immersion bright-field or fluorescence optics. While approaching a cell with the patch pipette, positive pressure was applied to the pipette, thereby blowing aside any material between the slice surface and the cell.

Membrane currents were measured with the patch-clamp technique in whole-cell recording configuration (Hamill et al., 1981). Current signals were amplified with conventional electronics (EPC-7 amplifier, List-Electronics, Darmstadt, Germany), filtered at $3 \mathrm{kHz}$, and sampled at $5 \mathrm{kIIz}$ by an interface conncctcd to an AT-compatible computer system, which also served as stimulus generator.

Solutions and electrodes. The standard bath solution contained (in mM) $\mathrm{NaCl}, 150 ; \mathrm{KCl}, 5.4 ; \mathrm{CaCl}_{2}, 2 ; \mathrm{MgCl}_{2}, 1 ; \mathrm{HEPES}, 5$; and glucose, 10. The $\mathrm{pH}$ was adjusted with $\mathrm{NaOH}$ to 7.3 . During preparation and storage of slices the ice-cold solution was gassed with pure $\mathrm{O}_{2}$ and during the patch-clamp experiment with air. In some experiments tetraethylammonium chloride (TEA) or $\mathrm{KCl}$ replaced an equimolar quantity of $\mathrm{NaCl}$. Recording pipettes were fabricated from borosilicate capillaries (Hilgenberg, Malsfeld, Germany), with resistances of 5-10 M $\Omega$. The pipette solution contained (in mM) $\mathrm{KCl}, 130 ; \mathrm{CaCl}_{2}, 0.5$; EGTA, 5; $\mathrm{MgCl}_{2}, 2$; HEPES, 10; and ATP, 3. Calcium activity was calculated to be approximately $11 \mathrm{~nm}$. The $\mathrm{pH}$ was adjusted with $\mathrm{NaOH}$ to 7.3. In addition, the pipette contained $1 \mathrm{mg} / \mathrm{ml}$ Lucifer yellow (LY) (Fluka, Neu-Ulm, Germany).

LY staining, photoconversion, and electron microscopy. During recording cells were dialyzed with the LY-containing patch-pipette solution. After recording the seal was destroyed by large hyperpolarizing current pulses to prevent the cell from being pulled out of the slice during retraction of the electrode. For electron microscopy the slices, containing only one LY-filled cell, were fixed overnight in a water-based solution containing paraformaldehyde (4\%), glutaraldehyde $(2 \%)$, sucrose $(4 \%)$, and cacodylate $(50 \mathrm{~mm})$ at $\mathrm{pH} 7.4$. The LY fluorescence was converted into a photooxidative process, which produced an electrondense 3,3'-diaminobenzidine (DAB) reaction product. The method followed closely that one described by Maranto (1982) with modifications reported by Sandell and Masland (1988). In short, slices were rinsed in $0.1 \mathrm{~m}$ Tris buffer ( $\mathrm{pH} 8.2$ ), placed on a microscope slide, and incubated in the reaction solution $(1.5 \mathrm{mg} \mathrm{DAB} / \mathrm{ml}$ Tris buffer, supplemented with $1.0 \mathrm{mg} \mathrm{KCN} / \mathrm{ml}$ to reduce background labeling). The LY-filled cells were irradiated for $30 \mathrm{~min}$ with UV light (bandpass $400-440 \mathrm{~nm}$ ) on a microscopic stage using a $25 \times$ or a $40 \times$ objective. Thus, it was possible to observe the fading of the LY and the formation of the brown DAB reaction product. After the conversion, the slices were returned into the fixation buffer.

For transmission electron microscopy the slices were washed in 0.05 M cacodylate buffer, $8.5 \%$ sucrose, postfixed in Dalton's osmium, and embedded into araldite. The same fixation procedure was applied to microglial cell pellets harvested from cell cultures prepared according to Frei et al. (1987).

Characterization of cells as macrophages/microglia in viable slices. After sectioning and prior to electrophysiology, brain slices were transferred into Dulbecco's modified Eagles medium (DMEM; Scrva, Hcidelberg, Germany) containing a fluorescein isothiocyanate (FITC)-coupled goat anti-rabbit antibody (diluted 1:20; Dianova, Hamburg, Germany), LY $(0.3 \%)$, or ac-LDL, labeled with $1,1^{\prime}$-dioctadecyl-1-13,3,3',3'-tetramethylindocarbocyanine perchlorate (Dil-ac-LDL) $(10 \mathrm{mg}$ / $\mathrm{ml}$; Paesel and Lorei, Frankfurt, Germany). Double labeling was obtained by incubation with both DiI-ac-LDL and the FITC-coupled antibody. Slices were incubated in $100 \mu \mathrm{l}$ of this medium, forming a thick drop on parafilm inside a loosely closed humidified petri dish. The petri dish was placed in an incubator (humidified atmosphere, $5 \%$ $\mathrm{CO}_{2}, 37^{\circ} \mathrm{C}$ ) for $30 \mathrm{~min}$ for prelabeling with antibody or for $4 \mathrm{hr}$ after completion of electrical recordings for identification of LY-filled cells. The medium contained 5\% horse serum (HS) for LY and DiI-ac-LDL staining. After the incubation, prelabeled slices were transferred into the recording chamber. For reexamination after recording, slices were washed for $15 \mathrm{~min}$ and fixed in $3 \%$ paraformaldehyde in $0.01 \mathrm{M}$ phosphate-buffered saline (PBS) for at least $2 \mathrm{hr}$.

Immunocytochemical characterizations of fixed slices. Two methods were employed to counterstain fixed slices containing LY-filled cells.
Immunocytochemical identification was achieved using the monoclonal antibodies Mac-1 and CD45 (Boehringer Mannheim, Mannheim, Germany) alone or in combination in order to enhance staining intensity. Slices were fixed in paraformaldehyde-lysine-periodate fixative (McLean and Nakane, 1974) for $3-4 \mathrm{hr}$ at $4^{\circ} \mathrm{C}$, washed in PBS (15 min), preincubated for $10 \mathrm{~min}$ in PBS containing 10\% HS (Boehringer Mannheim), incubated with the first antibody (Mac-1, diluted 1:100, and CD45, diluted 1:200 in PBS with 5\% HS) for $45 \mathrm{~min}$, washed in PBS containing $1 \% \mathrm{HS}$, incubated with anti-rat $\mathrm{IgG}$ antibody coupled to Texas red (Dianova; diluted 1:200 in 1\% HS-PBS) for $20 \mathrm{~min}$, and finally washed in $1 \%$ HS-PBS. As a control, unspecific rat IgG $2 b$ (generous gift from B. Kyewski, DKFZ, Heidelberg, Germany) antibody was used.

As a second method, we used the microglial-specific nucleoside diphosphatase (NDPase) reaction as previously described (Murabe and Sano, 1982). Stained slices were evaluated and photographed with a Zeiss Axiophot fluorescence microscope.

Exclusion of blood monocytes by perfusion. To exclude a contamination of the brain slices with blood monocytes during preparation, we anesthetized two mice with pentobarbitone $(60 \mathrm{mg} / \mathrm{kg}$; Labaz, Munich, Germany) and perfused them first with warm $\left(25^{\circ} \mathrm{C}\right)$ and then with icecold bath solution containing heparin (Braun, Melsungen, Germany; diluted $40 \mathrm{U} / 100 \mathrm{ml}$ ) prior to normal slice preparation.

\section{Results}

\section{A subpopulation of microglial cells can be identified in tissue slices}

In this study, we focused on a subpopulation of microglial cells at a defined stage of development. As will be shown below, these cells share many properties with microglial cells maintained in cell culture. This population could be identified by binding of DiI-ac-LDL. Apart from staining some round cells in the meninges and chorioid plexus, this method resulted in an intense labeling of a population of elongated or nearly globular cells ranging in size from 10 to $20 \mu \mathrm{m}$. These cells were located in the corpus callosum, cingulum, anterior commissure, the medial septal region, and subependymal above the lateral ventricles (Fig. $1 A-C$ ).

This population also stained positively for FC-receptors as revealed by double labeling with DiI-ac-LDL and FITC-coupled antibody. For a quantitative evaluation, 50 cells in the corpus callosum expressing both Fc-receptors and ac-LDL receptors were graded according to their cell body size on one hand, and DiI-ac-LDL fluorescence on the other. Cell sizes were divided into three groups, 5-7 $\mu \mathrm{m}$ (group 1), 8-10 $\mu \mathrm{m}$ (group 2 ), and more than $10 \mu \mathrm{m}$ (group 3). Fluorescent DiI-ac-LDL was found in vesicles within cells, and graded according to the number of vesicles within one cell: one or two vesicles (grade 1), several distinct vesicles (grade 2), cell partially filled with indistinguishable vesicles (grade 3 ), cell completely filled with fluorescent vesicles (grade 4). Eight cells were found in group 1 and their fluorescence averaged at grade $1.68 ; 23$ cells belonged to group 2 and were graded 2.40 ; the 19 cells of group 3 were graded 2.64 in their average DiI-ac-LDL fluorescence. This shows that the DiI-ac-LDL fluorescence was positively related to the cell size; that is, larger cells displayed a stronger labeling. A large number of ac-LDL-negative but Fc-receptor-positive cells were found not only in the brain regions described above, but throughout the whole coronal brain slice in both the gray and white matter (Fig. 1D). These cells were smaller than the acLDL-positive population and had several processes. The macrophage/microglial-specific monoclonal antibodies Mac-1 and CD-45 stained the cell surface of numerous cells with similar morphology and distribution as the Fc-receptor-positive cells, including also the cells that stained for ac-LDL (Fig. $1 E$ ). NDPase 
was used as an additional microglial marker and labeled the same cell population as that labeled by the FITC-coupled antibodies (see Fig. 3A).

In the slices prepared from the perfused mice no erythrocytes were detectable in the blood vessels upon careful microscopic examination in the recording setup, in contrast to the unperfused condition, where many erythrocytes were encountered. In both perfused and unperfused mice a similar number of cells with the typical morphology of ameboid microglia cells was observed.

\section{The microglial subpopulation can be recognized prior to or after patch-clamp recording using fluorescence microscopy}

To identify microglial cells prior to recording, cells were labeled with the methods described above. Microglial cells are known to have a high pinocytotic activity and to take up dyes like LY faster than other cells in the brain (Ranson and Thomas, 1991). After incubation of slices with an LY-containing bath solution for $30 \mathrm{~min}$, cells with a microglia-like morphology containing LY-filled vesicles were distributed over the entire slice. Pinocytosis of LY had the disadvantage that background fiuorescence was very high and it was difficult to identify individual cells for recordings. Better results were obtained by labeling the Fc-receptor of microglial cells with the FITC-coupled antibody (Fig. $1 D$ ). The fluorescence signal after $30 \mathrm{~min}$ of incubation was rather weak, but it was possible to obtain whole-cell recordings from these cells $(n=9)$. The $30 \mathrm{~min}$ of incubation appeared to be the best compromise between visibility and viability of the cells.

After gaining experience with the appearance of microglial cells in the corpus callosum, it was possible to recognize this cell population on the basis of morphological criteria only. Viewed with a $40 \times$ water immersion lens, more or less round cells (diameter between 7 and $15 \mu \mathrm{m}$ ) of dark appearance and with multiple vesicles of different sizes, located near or at the corpus callosum slice surface, were selected. After filling a cell with LY during electrical recordings, the slice was stained by one of the methods described above: two slices were incubated in DiI-ac-LDL solution and three with a combination of Mac-1 and CD-45, and two others were subjected to an NDPase reaction. All of these LY-filled cells were posilively identified as mononuclear phagocytes by these histological methods (Fig. 2). As they are resident in brain tissue they can be referred to as ameboid microglia.

\section{The recorded cells have ultrastructural features of ameboid microglia}

The recorded and LY-filled cells showed a strong staining with DAB after photoconversion. The nucleus of the labeled cells was oval and of irregular shape with dense chromatin patches beneath the nuclear membrane and throughout the nucleus. They showed an elongated and narrow granular endoplasmic reticulum and a prominent Golgi apparatus as typically seen in microglia and other macrophages. The most prominent features of these DAB-positive cells were irregular cytoplasmic protrusions and numerous vesicular structures like lysosomes, homogeneous droplets, and phagosomes (Fig. $3 B, D$ ). These structures are characteristic for migratory macrophages such as ameboid microglia in brain or in primary cell culture (Fig. 3E). They were located intraparenchymally but due to their high migratory activity they also appeared on the surface of the slice (Fig. 3A).

\section{Ameboid microglia cells have only inwardly rectifying currents like their cultured counterparts}

Microglial cclls have a distinct pattern of voltage-dependent membrane currents: depolarizing voltage steps from a holding potential of $-70 \mathrm{mV}$ activated only small currents; hyperpolarizing voltage steps, however, elicited large inward currents (Figs. $2 F, 3 C$ ). In response to voltage jumps to potentials neg-

Figure 1. Immunocytochemical identification of microglial cells in live brain slices. $A$, Distribution of ac-LDL-positive cells in a coronal brain slice of a postnatal day 8 mouse. "Hot spots" show up as areas with accumulation of fluorescent cells. The arrowheads point to both cinguli as the areas from which the recordings in this study were taken. $B$, In a schematic drawing of a coronal brain slice, the area shown in $A$ is outlined by a frame (arrow on cingulum). $a c a$, anterior commissure, $c c$, corpus callosum; $c g$, cingulum; $C P u$, corpus putamen; $e c$, external capsule; $f$, fornix; $L V$, lateral ventricle. $C$, DiI-ac-LDL-labeled cells in the cingulum at higher magnification. DiI-ac-LDL has been taken up by elongated or globular cells into vesicles of various size. Occasionally, short processes are seen on labeled cells. $D$, Fc-receptor binding of a FITC-coupled goat anti-rabbit antibody. The particular morphology of the labeled cells, characterized by a small cell body and multiple processes, can be observed in brain regions outside the "hot spots." Fc-receptors are present on all microglial cells, including the ameboid and ramified forms. $E$, A combination of the specific antibodies CD45 and Mac-l was used to label the surface of microglial cells after fixation. The photograph was taken from the medial septal region of a coronal brain slice. Scale bars: $A, 400 \mu \mathrm{m} ; C-E, 10 \mu \mathrm{m}$.

Figure 2. Immunocytochemical identification of recorded microglial cells. $A$, Interference contrast photomicrograph of NDPase-labeled cells in the corpus callosum of a postnatal day 7 mouse. The arrowhead points to a cell that was previously recorded from with the patch-clamp technique. $B$, In the same field as displayed in $A$, the LY-filled cell is visible. Note the fine processes with thickenings at the distal end. $C-E$, Interference contrast picture of a different cell $(C)$ that has been filled with LY $(E)$ and counterstained with Mac-1/CD45 antibodies $(D)$. Arrowheads point to the cell that was filled during patch-clamp recordings $(E) . F$, Corresponding membrane currents of the cell shown in $A$ were activated as described for Figure $3 C$. Scale bars: $A$ and $B, 16 \mu \mathrm{m} ; C-E, 10 \mu \mathrm{m}$.

Figure 3. Ultrastructural propertics of ameboid microglia. $A$, During incubation numerous migratory cells (arrow) appeared on the surface of the slice. They had the typical ultrastructural features of ameboid microglia: irregular nuclei with dense chromatin and numerous vesicles. $B$, An ameboid microglial cell located within the brain parenchyma was filled with LY during recordings and photoconverted, and can be recognized by the dark reaction product. The characteristic features of ameboid microglia, the cytoplasmic filopodia and a large number of vesicular structures, are present in this cell. $C$, The membrane currents of the identical microglial cell as shown in $B$ and $D$ were activated by depolarizing (up to +30 $\mathrm{mV}$ ) and hyperpolarizing (down to $-170 \mathrm{mV}$ ) the membrane from a holding potential of $-70 \mathrm{mV}$ (see inset). Hyperpolarizing voltage jumps down to $-170 \mathrm{mV}$ with an increment of $20 \mathrm{mV}$ activated large inward currents. Depolarizing voltage steps (up to $30 \mathrm{mV}$ ) with the same increment induced only minute outward currents. Note the inactivation of the current with large hyperpolarizing voltage steps. $D$, The cytoplasmic protrusions of this DAB-labeled cell appeared as abundant foldings of the membrane (arrows). The positive staining for Fc-receptors prior to recording and the membrane current pattern make it unlikely that this cell is a dark, "granulated" oligodendrocyte. Though the cell was disrupted during the dialysis by the patch-clamp procedure, the numerous vesicular structures can still be seen. $E$, A cultured microglial cell from rat brain shows similar prominent membrane foldings and a high number of vesicular structures, like lysosomes, homogeneous droplets, and phagosomes, as observed in the microglia of the slice preparation. Scale bars, $1 \mu \mathrm{m}$. 

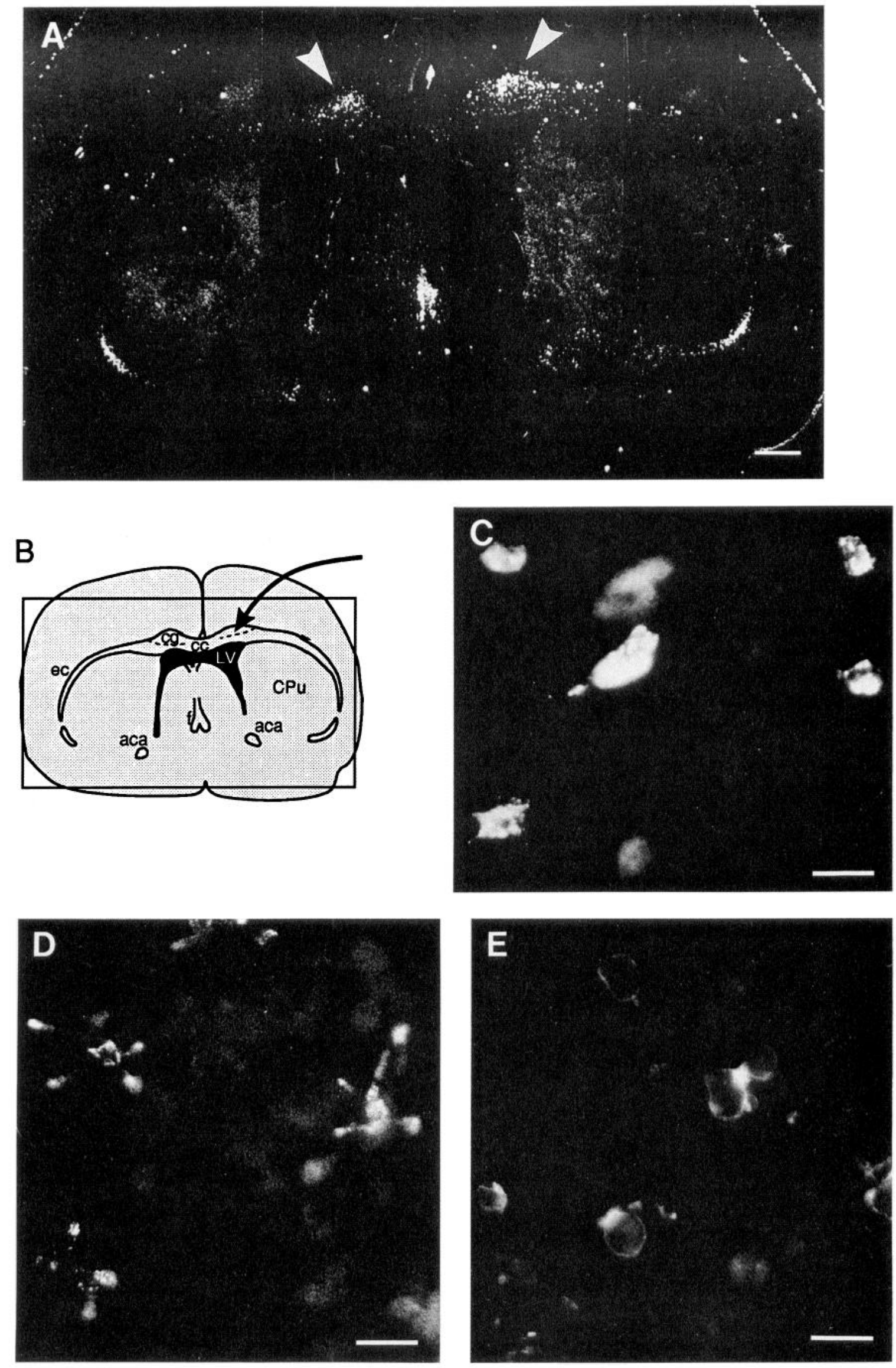

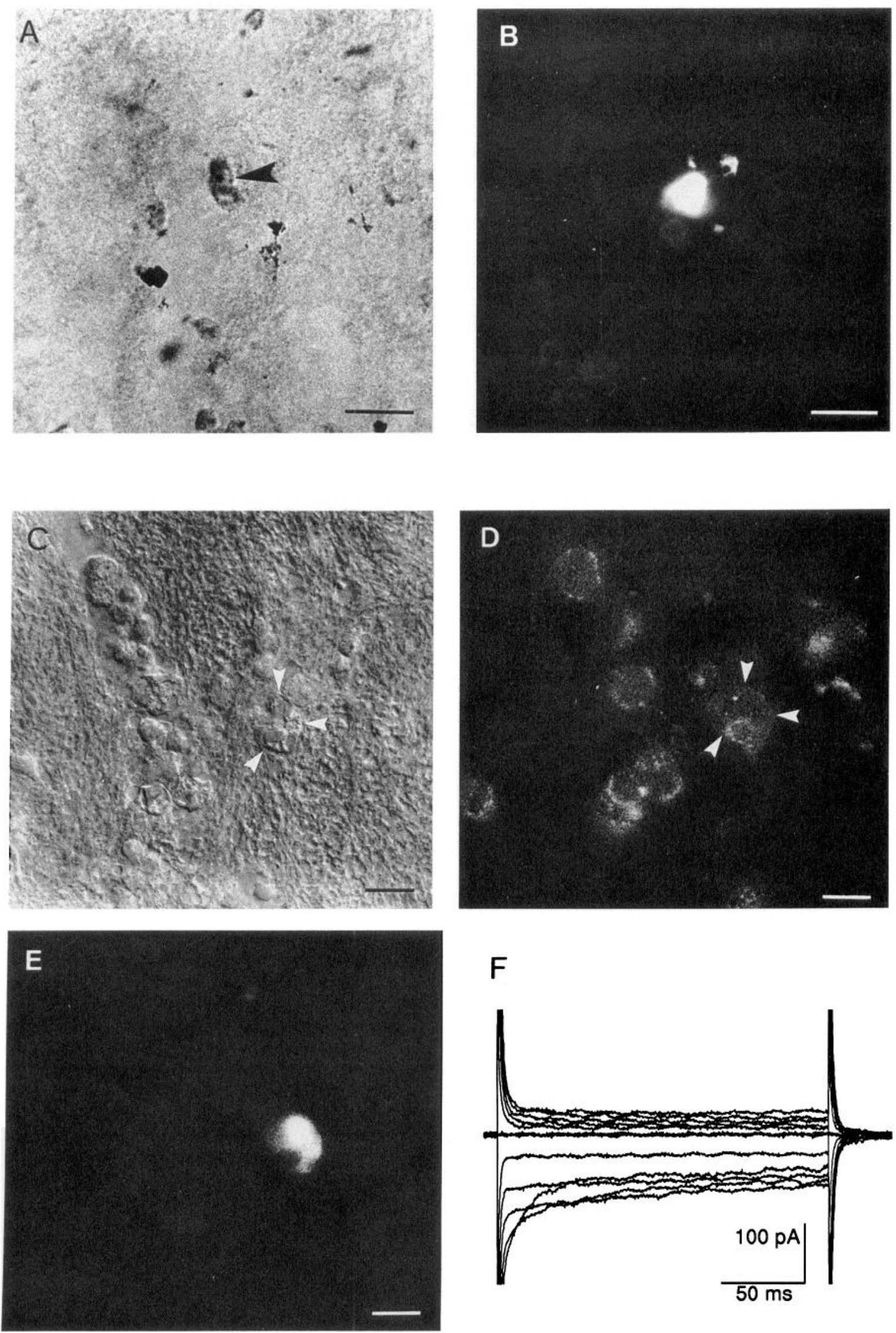


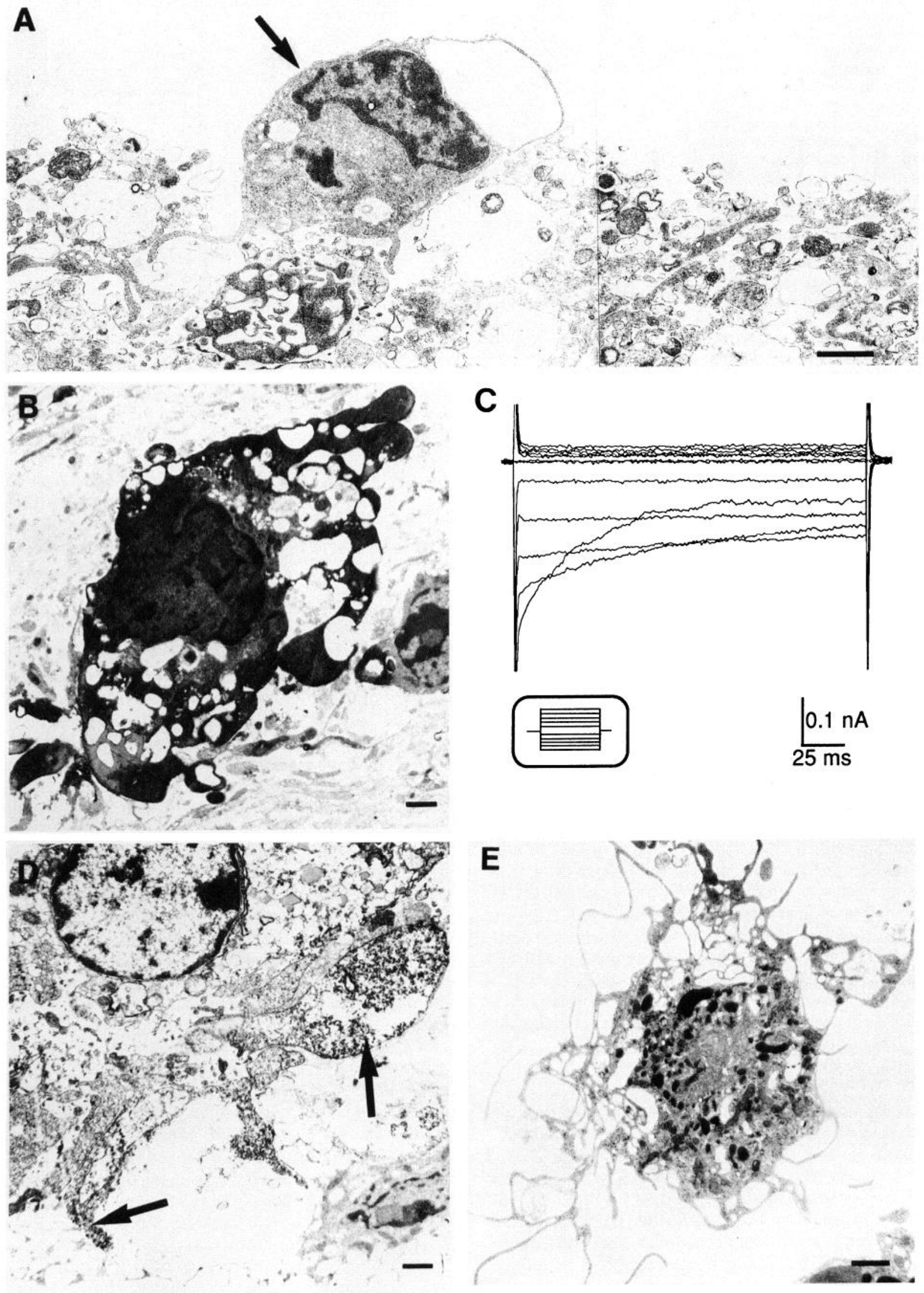


Figure 4. Inactivating properties of the inwardly rectifying current. $A$, A current $(I)$-voltage $(V)$ relation was obtained from a series of de- and hyperpolarizing voltage steps from a holding potential of $-70 \mathrm{mV}$. The family of current traces ranging from 20 to -170 $\mathrm{mV}$ with $10 \mathrm{mV}$ increments are shown in the inset. The peak currents (squares) were determined directly after the end of the capacitative artifact, the steady state currents (diamonds) in the last 20 $\mathrm{msec}$ of the voltage step. The inward rectification is apparent by the large amplitude of the inward, in contrast to the outward currents. $B$, The time constant of inactivation $(\tau)$ was determined from exponential functions fitted to a series of current traces activated as described for $A$ and is plotted against the membrane potential $(V)$. The inactivation time constant decreased with hyperpolarization.
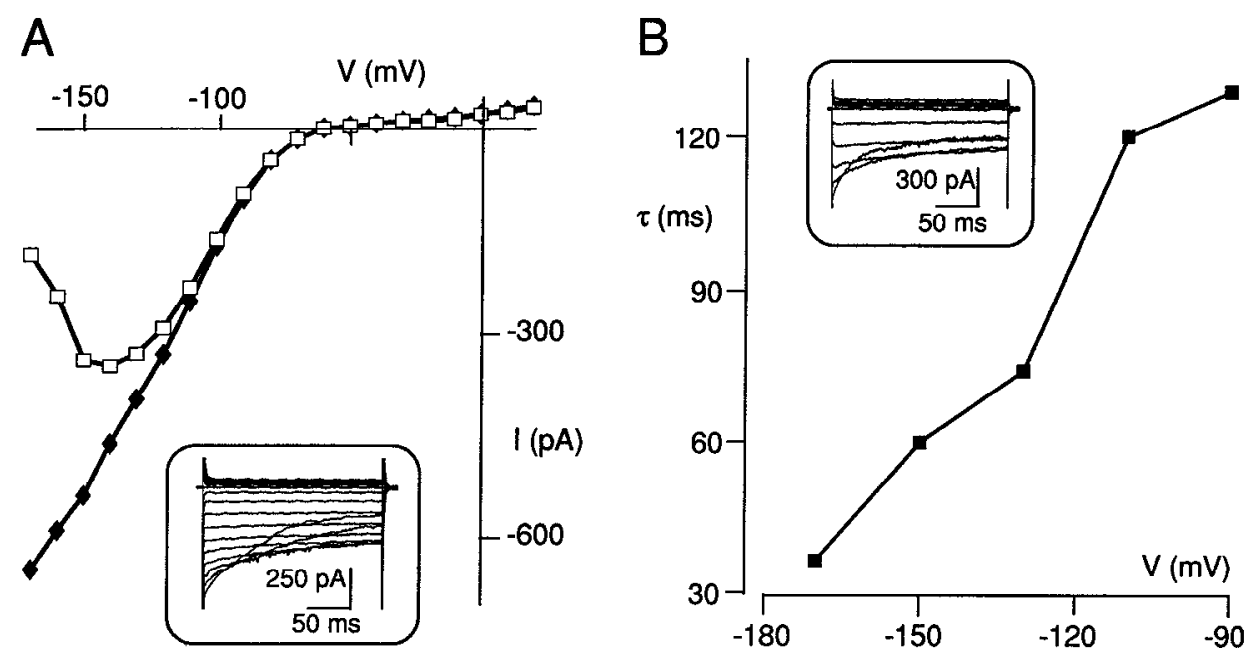

ative to $-100 \mathrm{mV}$, these inward currents inactivated. The rate of inactivation increased with larger hyperpolarization; thus, the steady state inward current after a voltage jump to -170 $\mathrm{mV}$ was often smaller than that of a jump to $-150 \mathrm{mV}$ (Fig. 4), observed in voltage jumps lasting for up to $1 \mathrm{sec}$ (not shown).

For hyperpolarizing voltage steps from -70 to $-170 \mathrm{mV}$, the mean peak current was $266 \mathrm{pA}$ ( $n=53$; range, $40-1150 \mathrm{pA}$ ), whereas the mean steady state current was $105 \mathrm{pA}(n=53$; range, $20-910 \mathrm{pA}$ ). To quantify the observed inward rcctification, we used the ratio between steady state outward currents and peak inward currents for a voltage jump of $\pm 100 \mathrm{mV}$ from the holding potential as an index. In cells with inward currents of more then $100 \mathrm{pA}(n=39)$, the inward current was at least twice as large as the outward current (mean, 6.7; range, 2.024.5). Also, the remaining cells with inward currents less than $100 \mathrm{pA}$ showed a ratio between inward and outward currents larger than 1 .

The small outward currents, if seen, were not voltage or time dependent, indicating that they did not result from the activation of voltage-gated $\mathrm{K}^{+}$channels.

The resting membrane potential of the microglial cells was measured shortly after disrupting the membrane with the patch pipette, assuming that the cell interior was not yet dialyzed (Pusch and Neher, 1987). It showed a high variability with a mean of $-42 \mathrm{mV}$ ( $n=53$; range, -10 to $-70 \mathrm{mV}$ ). There was no correlation between membrane potential and activated currents or difference in the pharmacological responses.

\section{The inward rectifier depends on the $K^{+}$gradient}

To identify the ionic specificity of the inwardly rectifying current, we compared currents using two different extracellular $\mathrm{K}^{+}$ concentrations $\left(\left[\mathrm{K}^{+}\right]_{o}\right)$. When the cells were clamped at -70 $\mathrm{mV}$, an increase in $\left[\mathrm{K}^{+}\right]_{o}$ from 5.4 to $55 \mathrm{~mm}$ induced a large inward current with a mean of $334 \mathrm{pA}(n=12$; range, 45-800 pA) (Fig. 5A). In another set of experiments, we compared the voltage-dependent currents in normal and high $\left[\mathrm{K}^{+}\right]_{o}$ in response to de-and hyperpolarizing voltage steps from the holding potential (Fig. 5B,C). Peak currents were plotted as a function of the membrane potential. The current-voltage relation in high $\left[\mathrm{K}^{+}\right]_{o}\left(55 \mathrm{mM} ; E_{K}=-23 \mathrm{mV}\right)$ compared to normal $\left[\mathrm{K}^{+}\right]_{o}(5.4$ mм; $E_{K}=-79 \mathrm{mV}$ ) showed a shift in the reversal potential (e.g., $-76 \mathrm{mV}$ to $-20 \mathrm{mV}$, see Fig. $5 C$ ) correlated to the change in the $\mathrm{K}^{+}$equilibrium potential. The correlation indicates that these inwardly rectifying currents were largely carried by $\mathrm{K}^{+}$ ions, similar to those described in muscle cells (Sakmann and Trube, 1984a,b).

\section{The inward current has the pharmacological profile of the inward rectifier}

To characterize further the inwardly rectifying current, we tested the effect of the $\mathrm{K}^{+}$channel blockers TEA, 4-aminopyridine (4$\mathrm{AP})$, and $\mathrm{Ba}^{2+}$. With a voltage-clamp protocol, the membrane was depolarized or hyperpolarized for periods of $100 \mathrm{msec}$ to $-40,-20,0,20,-100,-120,-140$, and $-160 \mathrm{mV}$ with 200 msec intervals at the holding potential of $-70 \mathrm{mV}$. This voltageclamp protocol was applied every $6 \mathrm{sec}$ and enabled us to construct current-voltage curves and determine reversal potentials for each set of voltage jumps. Extracellular application of $\mathrm{Ba}^{2+}$ ( 2 or $5 \mathrm{~mm}$ ) almost completely blocked the inwardly rectifying currents; the current-voltage relation became linear $(n=17)$ (Fig. $6 \mathrm{~A}$ ); a complete recovery of the response was reached after 15-20 min. Currents were reversibly reduced by TEA (50 mM) ( $n=5$; mean, $64 \%$ of control; range, 52-89\%) (Fig. $6 B$ ). 4-AP ( 5 or $10 \mathrm{~mm}$ ), known to block specifically the delayed rectifier and the A subtype of $\mathrm{K}^{+}$channels (Rudy, 1988), led to only a small or no reduction of the response ( $n=8$; mean, $4 \%$; range, 0-14\%) (Fig. 6C).

\section{Discussion}

The selected highly pinocytotic and ac-LDL-positive population is the ameboid form of microglia

In this study we focused on a defined population of cells that have a number of properties identifying them as microglial cells and distinguishing them from neurons, astrocytes, and oligodendrocytes. They have a high rate of pinocytosis, and express Fc-receptors, CD45 and Mac-1 surface antigens, and the membrane-bound enzyme NDPase. Further, they have the ultrastructural features of microglia, that is, the oval, sometimes irregular nucleus with prominent chromatin. They have no stacks of glial fibrillary acidic protein as astrocytes do, and the cyto- 

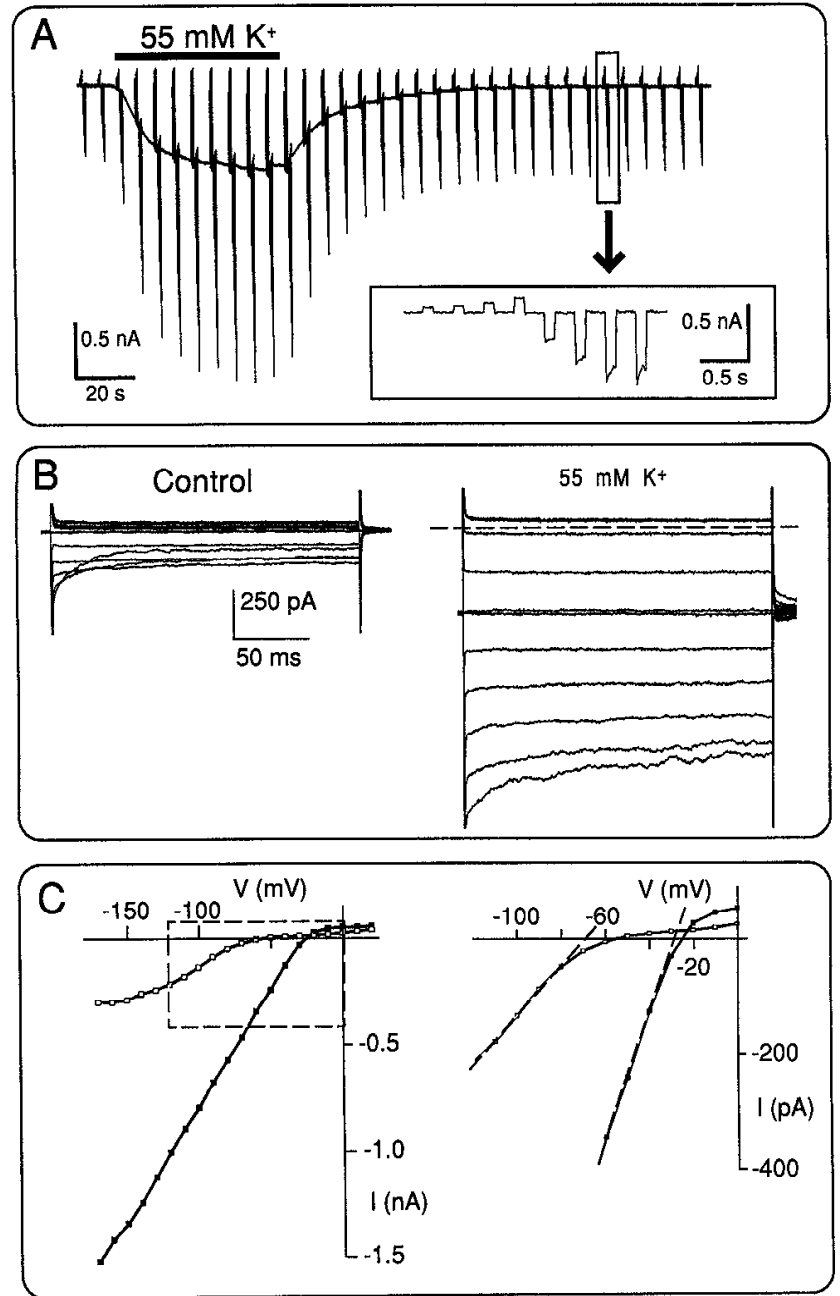

Figure 5. Dependence of the inwardly rectifying current on the $\mathrm{K}^{+}$ gradient. $A$, Currents were recorded while clamping the membrane for $100 \mathrm{msec}$ to depolarizing $(-40,-20,0,+20 \mathrm{mV})$ and hyperpolarizing potentials $(-100,-120,-140$, and $-160 \mathrm{mV})$ from the holding potential of $-70 \mathrm{mV}$ as shown in the inset on a longer time scale. This clamp protocol was repetitively applied in $6 \mathrm{sec}$ intervals. $\left[\mathrm{K}^{+}\right]_{0}$ was increased from 5.4 to $55 \mathrm{~mm}$ as indicated by the horizontal bar. An inward current was induced at the holding potential (zero current level) and the currents in response to the voltage step increased in amplitude. $B$, The same protocol as described in for Figure 4 (increment $10 \mathrm{mV}$ ) was used to activate membrane currents in two different $\left[\mathrm{K}^{+}\right]_{o}, 5.4 \mathrm{~mm}$ (left traces) and $55 \mathrm{~mm}$ (right traces). In high $\left[\mathrm{K}^{+}\right]_{o}$ there was a constant inward current at the holding potential; the zero level is indicated by the broken line. Note that the inactivation of the inward current is less pronounced in $55 \mathrm{~mm}\left[\mathrm{~K}^{+}\right]_{\circ} . C$, From the recordings shown in $B$, current $(I)$-voltage $(V)$ curves of the peak currents (determined as described for Fig. $4 A$ ) were constructed in $5.4 \mathrm{~mm}$ (open squares) and $55 \mathrm{~mm}\left[\mathrm{~K}^{+}\right]_{o}$ (solid squares). To illustrate the reversal potential of currents more clearly, a selected area from the left graph is shown expanded in the right graph. The broken lines were fitted by eye to the linear region of the current-voltage curve indicating a reversal potential at $-70 \mathrm{mV}$ in $5.4 \mathrm{mM}\left[\mathrm{K}^{+}\right]_{o}$ and at $-29 \mathrm{mV}$ in $55 \mathrm{~mm}\left[\mathrm{~K}^{+}\right]_{o}$. The corresponding potassium equilibrium potentials are -79 and $-23 \mathrm{mV}$, respectively.

plasm is markedly brighter than in oligodendrocytes. In contrast to resting microglia, ameboid microglia possess ac-LDL receptors, prominent cytoplasmic filopodia, and a high number of vesicular structures. However, apart from their location there are no markers to distinguish these cells from other macrophages. All of their immunocytochemical and ultrastructural features can also be found in non-brain-derived macrophages.
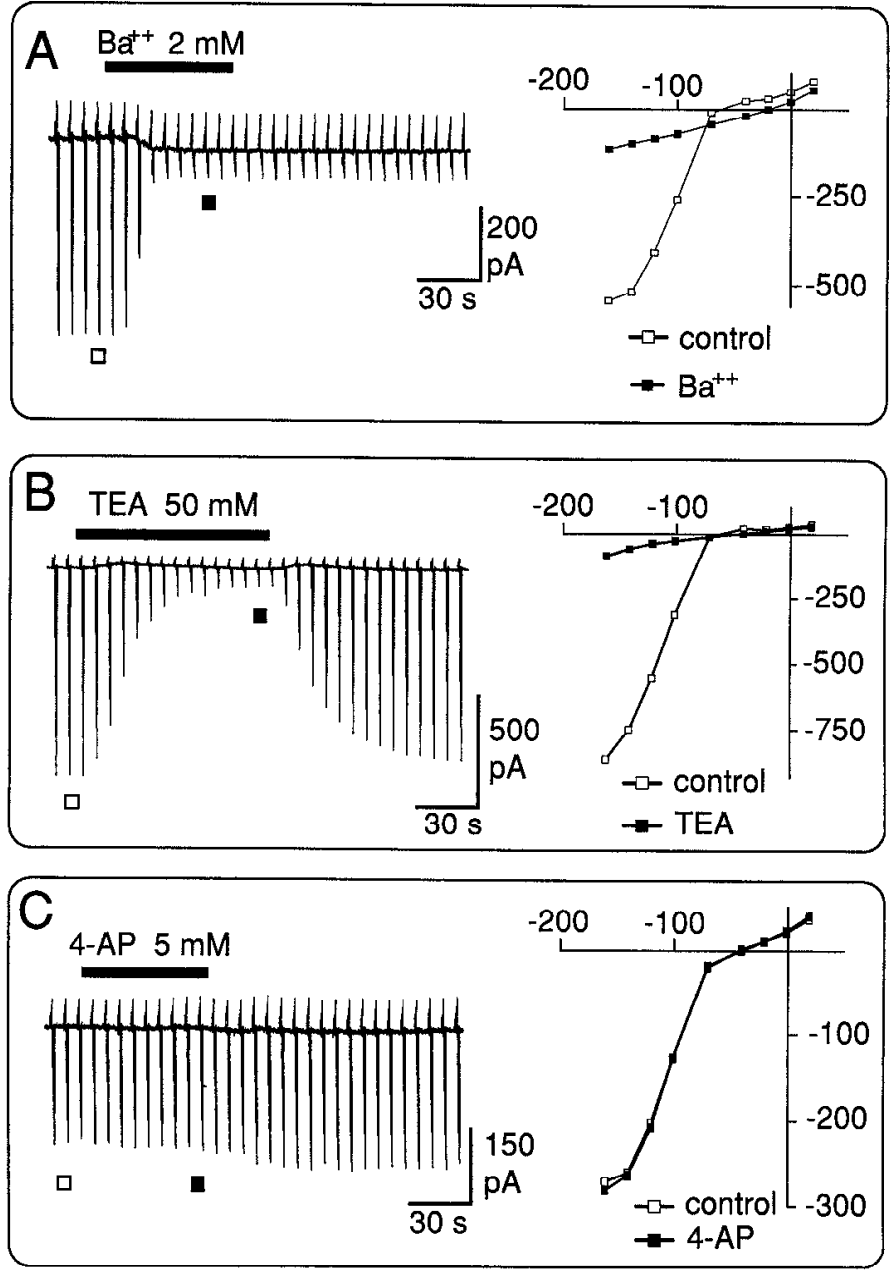

Figure 6. Pharmacological properties of the inwardly rectifying current. The voltage-clamp protocol as described for Figure $5 A$ was used to study the effect of the $\mathrm{K}^{+}$channel blockers $\mathrm{Ba}^{2+}(A)$, TEA $(B)$, and 4-AP $(C)$ applied as indicated by the horizontal bars. From a series of voltage steps, the current-voltage relation of the peak currents (determined as described for Fig. 4A) was constructed and is displayed on the right. A series of voltage steps in control solution (open squares) is compared to that in the presence of the corresponding $\mathrm{K}^{+}$channel blocker (solid squares). Inward currents were strongly blocked in the presence of TEA and $\mathrm{Ba}^{2+}$, while 4-AP had no apparent effect. The recovery period from the $\mathrm{Ba}^{2+}$ induced blockade lasted up to $20 \mathrm{~min}$ (not shown).

A special effort was made to exclude the possibility of recording from blood monocytes by perfusing two animals prior to preparation of brain slices. No difference in the number of cells with the typical morphology of ameboid microglial cells was noted after perfusion. We conclude from these data that the cells we recorded from are part of a population of ameboid and migratory microglial cells. A distinct population of large ameboid microglia cells has been described and given different names by several authors during early postnatal development in brain regions identical to the areas where ac-LDL staining was observed in our experiments ("ameboid," Murabe and Sano, 1982; "globular", Boya et al., 1979; "polycystic cells," Caley and Maxwell, 1968; "supraventricular ameboid microglia cells, SAMC," Leong and Ling, 1992). There are also different views on whether they are of the same origin and whether they will differentiate into resting or ramified microglia. Recently, it has been demonstrated that cells labeled as round supraventricular cells, cor- 
responding to our ac-LDL-positive population, transformed into typical ramified microglia (Leong and Ling, 1992). This observation is in agreement with, for example, del Rio-Hortega's (1932) and Murabe and Sano's (1982) notion that microglia are mesodermal cells that transform within the brain according to the structure of the locial environment. A different view is represented by a minority of researchers based on immunocytochemical (Chugani et al., 1991) and anatomical evidence (Hutchins et al., 1990). These authors propose that there are different origins of ameboid and ramified microglia, respectively.

The ameboid microglia in the slice share many properties with cultured microglial cells

Microglial cells can bc isolated from brain tissuc and maintaincd in cell culture (Giulian and Baker, 1986; Frei et al., 1987). This cell population does not represent a resting form of microglia, but rather the ameboid form (Giulian and Baker, 1986). This activated form is characterized by migratory and phagocytic activity and binding of ac-LDL. In this study, we found that the selected population of cells from a slice preparation shares many properties with these cultured ameboid cells (Fig. $3 E$ ). We have demonstrated that the majority of cells selected according to our criteria show a channel pattern similar to the one described in cultured microglial cells (Kettenmann et al., 1990) or a microglial cell line (Bocchini et al., 1992) and are thus distinct from cultured non-brain-derived macrophages. This channel pattern has otherwise only been described in a subpopulation of cells isolated from bone marrow (Banati et al., 1991). However, no comparable data are available on resident macrophages in slice preparations of other tissucs such as Kupffer cells in the liver or macrophages in the spleen. Our study supports the view that microglial cells develop from monocytic cells invading the brain in late embryonic and early postnatal periods.

Since we have focused on a particular brain area and developmental stage and a cell type with defined morphological properties, we cannot exclude that other forms of microglial cells, for example, resting microglia, express a different channel pattern. Recent studies (Nörenberg et al., 1992) indicate that cultured microglia with only inwardly rectifying currents can transform and express additional outwardly rectifying currents when stimulated with lipopolysaccharide. Korotzer and Cotman (1991) observed in another culture system a variety of current patterns that they attributed to microglial cells. Our study confirms that the population of cultured microglia, which is characterized by predominant cxpression of an inwardly rectifying current, arc derived from an intrinsic brain cell population; for cultured microglial cells expressing other current patterns, this still needs to be demonstrated.

\section{The inward rectification is due to an inwardly rectifying $K^{+}$ current}

The inwardly rectifying current was found to be a $\mathrm{K}^{+}$-selective current since its reversal potential is close to the $\mathrm{K}^{+}$equilibrium potential and the current is blocked by $\mathrm{Ba}^{2+}$ and TEA, similar to inwardly rectifying $\mathrm{K}^{+}$currents described in other cell types (e.g., Sakmann and Trube, 1984a). Also, the following observations support the view that this current is due to the classical inward rectifier: the current inactivates at negative potentials, and the inactivation time constant decreases with increasing hyperpolarization. Moreover, the conductance increases and the inactivation disappears in elevated extracellular $\mathrm{K}^{+}$as described for inward rectifiers (Sakmann and Trube, 1984a,b). These findings are also in agreement with the studies on cultured microglial cells (Kettenmann et al., 1990).

\section{Functional implications for a cell with inwardly rectifying membrane properties}

The lack of outward currents in microglial cells as described in culture (Kettenmann et al., 1990) and in this slice preparation has the functional consequence that the depolarization evoked by an inward current will not be curtailed by outward currents. Therefore, agents that depolarize cells will lead to larger and longer-lasting depolarizations in microglial cells than in other cells such as macrophages or astrocytes, which have outward currents. Such a sustained depolarization could be important for the induction of subsequent intracellular events. Indeed, extracellularly applied ATP leads to a long-lasting inward current in cultured microglial cells and could thus function as such an agent (Kettenmann et al., 1993; Walz et al., 1993). Since ATP may be released by damaged brain cells, it could serve as a stimulus for ameboid microglia to respond to brain damage. We are, however, beginning to understand the receptive repertoire, the signal transduction pathways and the physiological responses of microglia during development, normal brain function, and regeneration. Assessing microglial cells in tissue slices with modern electrophysiological methods will help to elucidate the functional diversity of microglia.

\section{References}

Banati RB, Hoppe D, Gottmann K, Kreutzberg GW, Kettenmann H (1991) A subpopulation of bone marrow derived macrophages share a unique ion channel pattern with microglia. J Neurosci Res 30:593600.

Berger T, Schnitzer J, Kettenmann H (1991) Developmental changes in the membrane current pattern, $\mathrm{K}^{+}$buffer capacity and morphology of glial cells from the corpus callosum slice. J Neurosci 11:3008. 3024.

Bocchini V, Mazzolla R, Barluzzi R, Blasi E, Sick P, Kettenmann H (1992) An immortalized cell line expresses properties of activated microglial cells. J Neurosci Res 31:616-621

Boya J, Calvo J, Prado A (1979) The origin of microglial cells. J Anat 129:177-186.

Caley DW, Maxwell DS (1968) An electron microscopic study of the neuroglia during postnatal development of the rat cerebrum. J Comp Ncurol 133:45-70.

Chugani DC, Kedersha NL, Rome LH (1991) Vault immunofluorescence in the brain: new insights regarding the origin of microglia. $J$ Neurosci 11:256-268.

del Rio-Hortega P (1921) Histogenesis y evolucion normal; exodo y distribution regional de la microglia. Mem R Soc Espan [Hist Nat] 11:213-267.

del Rio-Hortega P (1932) Microglia. In: Cytology and cellular pathology of the nervous system, Vol 2 (Penfield W, ed), pp 481-548. New York: Hoeber.

Dickson DW, Mattiace LA, Kure K, Hutchins K, Lyman WD, Brosnan CF (1991) Biology of disease. Microglia in human disease, with an emphasis on acquired immune deficiency syndrome. Lab Invest 64: 135-156.

Frei K, Siepl C, Groscurth P, Bodmer S, Schwerdel C, Fontana A (1987) Antigen presentation and tumor cytoxicity by interferon-gammatreated microglial cells. Eur J Immunol 17:1271-1278.

Giulian D, Baker TJ (1986) Characterization of ameboid microglia isolated from developing mammalian brain. J Neurosci 6:2163-2178.

Giulian D, Chen J, Ingeman JE, George JK, Noponen M (1989) The role of mononuclear phagocytes in wound healing after traumatic injury to adult mammalian brain. J Neurosci 9:4416-4429.

Graeber MB, TetzlaffW, Streit W., Kreutzberg GW (1988) Microglial cells but not astrocytes undergo mitosis following rat facial nerve axotomy. Neurosci Lett 85:317-321. 
Hamill OP, Marty A, Neher E, Sakmann B, Sigworth FJ (1981) Improved patch clamp techniques for high resolution current recording from cells and cell-free membrane patches. Pfluegers Arch 391:85100.

Hickey WF, Vass K, Lassmann H (1992) Bone marrow-derived elements in the central nervous system: an immunohistochemical and ultrastructural survey of rat chimeras. J Neuropathol Exp Neurol 51: 246-256.

Hutchins KD, Dickson DW, Rashbaum WK, Lyman WD (1990) Localization of morphologically distinct microglial populations in the developing human fetal brain: implication for ontogeny. Dev Brain Res 55:95-102.

Kershmann J (1939) Genesis of microglia in the human brain. AMA Arch Neurol Psychiatry 41:24-50.

Kettenmann H, Hoppe D, Gottmann K, Banati RB, Kreutzberg GW (1990) Cultured microglial cells have a distinct pattern of membrane channels different from peritoneal macrophages. J Neurosci Res 26: 278-287.

Kettenmann H, Banati RB, Walz W (1993) Electrophysiological behaviour of microglia. Glia 7:93-101.

Korotzer AR, Cotman CW (1991) Delayed rectifier current expressed by cultured rat microglia. Soc Neurosci Abstr 17:1149.

Leong SK, Ling EA (1992) Ameboid and ramified microglia: their interrelationship and response to brain injury. Glia 6:39-47.

Maranto AR (1982) Neuronal mapping: a photooxidation reaction makes Lucifer yellow useful for electron microscopy. Science 217 : 953-955.

McLean IW, Nakane PK (1974) Periodate-lysine-paraformaldehyde fixative. A new fixative for immunoelectron microscopy. J Histochem Cytochem 22:1077-1083.
Murabe Y, Sano Y (1982) Morphological studies on neuroglia. VI. Postnatal development of microglial cells. Cell Tissue Res 225:469485.

Nörenberg W, Gebicke-Haerter PJ, Illes P (1992) Inflammatory stimuli induce a new $\mathrm{K}^{+}$outward current in cultured rat microglia. Neurosci Lett 147:171-174.

Perry VH, Hume DA, Gordon S (1985) Immunohistochemical localization of macrophages and microglia in the adult and developing mouse brain. Neuroscience 15:313-326.

Pusch M, Neher E (1987) Kinetics of loading small cells with various compounds by use of patch pipettes. Pfluegers Arch [Suppl] 408:338.

Ranson PA, Thomas WE (1991) Pinocytosis as a select marker of ramified microglia in vivo and in vitro. J Histochem Cytochem 39: 853-858.

Rudy B (1988) Diversity and ubiquity of K channels. Neuroscience 25:729-750.

Sakmann B, Trube G (1984a) Conductance properties of single inwardly rectifying potassium channels in ventricular cells from guineapig heart. J Physiol (Lond) 347:641-657.

Sakmann B, Trube G (1984b) Voltage-dependent inactivation of inwardly rectifying single channel currents in guinea-pig heart cell membrane. J Physiol (Lond) 347:659-683.

Sandell JH, Masland RH (1988) Photoconversion of some fluorescent markers to a diaminobenzidine product. J Histochem Cytochem 36: 555-559.

Streit WJ, Graeber MB, Kreutzberg GW (1988) Functional plasticity of microglia: a review. Glia 1:301-307.

Walz W, Ilschner S, Ohlemeyer C, Banati RB and Kettenmann H (1993) $\mathrm{P}_{2}$-purinergic receptor-induced currents in cultured microglial cells. $\mathrm{J}$ Neurosci, in press. 